\title{
European legal developments in product safety and liability: The role of customer complaint management as a defensive marketing tool
}

\section{Ko de Ruyter and Antoni Brack}

University of Twente, Enschede, the Netherlands

In view of recent European legal developments, our purpose in this article is to position customer complaint management as an essential instrument for a defensive marketing strategy, specifically to prevent legal problems in the fields of product liability and product safety.
Correspondence to: J.C. de Ruyter, University of Twente, School of Management Studies, P.O. Box 217, 7500 AE Enschede, the Netherlands.

* The authors would like to express their gratitude to an anonymous reviewer who suggested many improvements to a draft version of this paper.

Intern. J. of Research in Marketing 10 (1993) 153-164 North-Holland

\section{Defensive marketing}

In order to expand market share and increase sales most firms spend much effort in attempts to attract new customers. This "offensive" objective in marketing strategy directs marketing "actions" (Bonoma, 1985) such as promotion and pricing. Recent economic and forthcoming political developments in Europe will make it difficult to meet such an objective. Many firms operate in mature or shrinking markets in which it is hard and costly to generate new customers as price and quality differences between products are becoming less clear. In addition, competition from both domestic and foreign rivals will intensify in the newly formed internal market in Europe. Therefore, it becomes important and profitable to retain current customers and to increase their purchase frequency. These developments are parallelled by a number of recent developments in the legal field. Particularly with regards to product safety and liability, European regulations have changed considerably. As a result of these developments, companies are more likely to be confronted with customer liability claims in the future. Ways of defense against potential liability claims will become a major issue. From a marketing-strategic point of view, the focus is shifting from offensive to defensive. While offensive marketing focuses on generating new customers, the defensive marketing strategy aims at building up a relationship with customers that leads to customer loyalty and repurchase behaviour and 
prevent legal action. Crucial to such a relationship is the level of customer satisfaction. The central objective of defensive marketing then is to maximize customer satisfaction or, alternatively, to minimize customer dissatisfaction.

Thus far, defensive marketing has not been defined in terms of customer (dis)satisfaction very often. Instead the focus, both in theory and in practice, has been almost exclusively on competitive interaction. Hauser and Shugan (1983), Hauser and Gaskin (1984), and Hauser (1984), for instance, deal with defensive marketing strategy in terms of the reaction of established brands to the introduction of new competitive brands. Their analysis suggests that such actions as lowering distribution and awareness advertising budgets and increased pricing in segmented markets will have a positive effect on customer retention. Fornell and Wernerfelt (1987; 1988) approach the concept of defense from a customer dissatisfaction perspective. They define the defensive marketing concept in terms of retaining dissatisfied customers. On the basis of Hirschman's exit-voice theory (Hirschman, 1970) they argue that a dissatis- fied customer can either switch brands (exit) or voice his dissatisfaction by filing a complaint. $\mathrm{Cus}^{+}$mer exit can cause considerable loss in markut share and sales, whereas complaints provide the firm with a chance to restore customer satisfaction and loyalty and provide information that can prevent future dissatisfaction (De Ruyter, 1990). Therefore, Fornell and Wernerfelt $(1987 ; 1988)$ argue that complaint management is an important marketing action with which the defensive marketing strategy can be operationalized. They show that by maximizing the number of complaints and hence satisfying complainants and increasing customer loyalty, organizations can gain market share or reduce their "offensive" marketing expenditure.

The strategic marketing advantages of complaint management are often not exploited to their full potential (Fornell and Wernerfelt, 1988; Fornell, 1988). In many organisations complaint handling is viewed as an ad-hoc activity that is to be kept to a minimum by discouraging dissatisfied customers from complaining (TARP, 1986). As a result the most cited reasons for not complaining were "it's not worth the trouble",

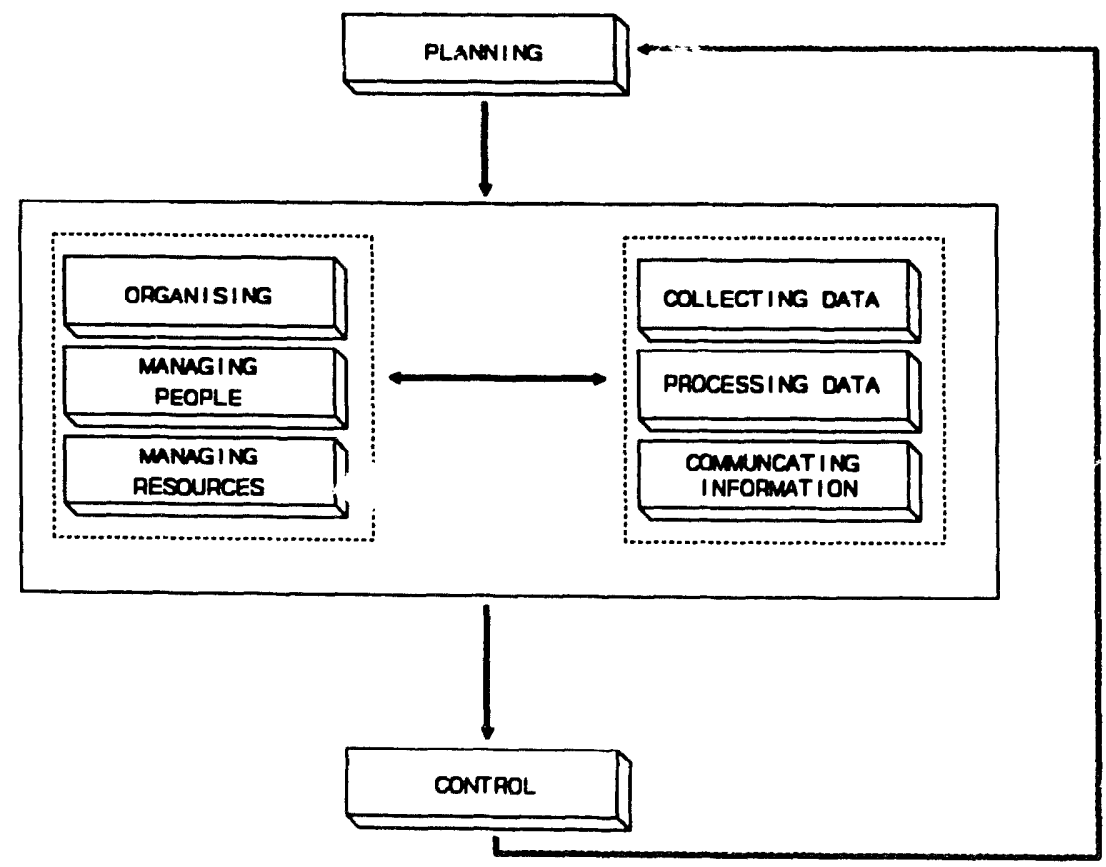

Fig 1 . The complaint management system. 
"no one cares" and "there is no useful or known channel for complaining" (TARP, 1986). Flaws in complaint management practice are matched by flaws in complaint management theory. Gilly and Stevenson (1988) conclude that complaint management is still an "underresearched" field of academic interest in which a comprehensive and systematic framework seems to be lacking. We will, therefore, on the basis of organisational theory develop a model for complaint management systems. After that we will discuss the significance of this defensive marketing tool for preventing the escalation of customer dissatisfaction in the form of product liability claims.

\section{Customer complaint management}

The "core business" of complaint management is transforming consumer contacts into information for both the individual customer and the management of the organisation (Fornell, 1988). Complaint management functions relating to this are: data collection, data analysis and communication of information. In order to direct complaint management's primary functions it is necessary to set objectives and investigate whether these are met. Therefore, we distinguish the directive functions of planning and control (Mintzberg, 1979). In addition, complaint management requires an infrastructure that provides certain facilities and conditions (Riemer, 1986). This requires resources, people and organisational arrangements. The complaint management system can be depicted as in Fig. 1.

We will now briefly discuss the eight functions of the complaint management system while integrating the key findings of the literature on complaint management.

Planning basically concerns a statement of what ends should be achieved by means of the complaint management system and how.
In general the two most common objectives of complaint management are: (1) to restore satisfaction of the individual complainant and (2) to provide management information on the basis of which dissatisfaction can be prevented in the future. In complaint management practice basically two courses of action are employed to achieve these objectives. Many organizations try to minimize the number of complaints (Fornell and Westbrook, 1984). However, as Fornell and Wernerfelt $(1987 ; 1988)$ state, it is more advantageous to maximize the number of dissatisfied consumers who complain since complaints enable the organisation to reestablish customer loyalty, to prevent escalation in the form of liability claims and to gather feedback from customers. The strategy of complaint maximization is, of course, subjected to certain cost constraints. Costs form part of the third planning activity, budgeting. Initial costs for complaint management are design and development or purchase of hardware and software, office space and equipment, telecommunications equipment, consultancy contracts, training and education, capital costs etc. Examples of operation costs are personnel, internal research, communication and analysis, system maintenance etc. (Riemer, 1986).

Collecting data refers to the input function of complaint management. This means first of all recording complaint data elements such as product type, product name, model and size, point of purchase, reason for problem, name, address, phone number of the complainant, date of incident, production number of the product involved, date of complaint, complainant's commentary, etc. To put this complaint data into perspective we propose to collect additional dissatisfaction related data as well. This may include warranty data, repair data, the number of customers that are dissatisfied but do not complain, data from billing and account records etc. 
Processing data forms the throughput function of complaint management. It consist of screening, classifying and analyzing customer complaints. Although a lot of complaints can usually be solved at first contact, a small number requires special attention. These include potential legal liability claims, new problems, repeat complaints etc. By careful screening such cases can be singled out. Complaint data can be divided into coded and non-coded data (Anton and De Ruyter, 1991). Coded data can be grouped into finite set of categories. Examples are product type, product name, model and size, point of purchase, reason for problem etc. Non-coded data is unique to the individual complainant. Non-coded data differs from case to case. Examples of non-coded data are name, address, phone number, date of incident, production number of the product involved, date of complaint, customer's commentary, etc. Quantitative and qualitative analysis of data completes this complaint management function. Statistical analysis allows for comparison between data variables such as the number of complaints by time (trend analysis), complaints by organisational function, complaints by retail outlet. Qualitative analysis refers, for example, to text analysis of complainants' commentaries. This may be of equal interest to company management as statistical reports (Goodman et al., 1988).

Communicating information forms the output element of the complaint management system. Communication takes place with two target groups: company management as internal customers and complainants as external customers. With respect to internal customers, management information generated from consumer complaints can be of use to Marketing (e.g., Wimmer, 1985), Quality Assurance (e.g., Goodman and Malech, 1985), Research and Development (Hansen, 1986) and Legal Affairs (e.g., Ulincy, 1989). Empirical research by Kasper (1982) identified a large variety of typical corporate customers of complaint information. In a survey conducted in the Netherlands he found that management information on the basis of customer complaints was sent to such organisational functions as Production (28\%), Marketing (24\%), Quality Control (17\%), Product Development (10\%), Service (4\%), Sales (19\%), Purchasing (4\%), Administration/ Accounting (4\%), Consumer Services (5\%), Laboratories (13\%). As far as communication with external customers is concerned, TARP (1986) found that factors of importance were: meeting customer expectations, reassurance if the problem cannot directly be solved, comprehensiveness, clarity, accuracy and timeliness.

Organizing is the first of the supportive functions for complaint management. It can be approached from (1) the organisational level and (2) the functional level. At the organisational level aspects that have to be taken into consideration are place within the organisational structure, reporting relationship and integration into organisational decision-making. At the functional level we look at size, structure and job specifications (e.g., data entry, analysis etc.) within the complaint managing department itself.

Managing people deals with the human resources management of the complaint management unit. This includes such activities as selecting, training and motivating personnel. Fornell (1976) found that the majority of Consumer Affairs managers were recruited from within the organisation. Advantages of in-company recruitment are a knowledge of the organisation's products and procedures (TARP, 1986; Riemer, 1986), the presence of informal ties and internal constituencies and personal recognition based on experience (Conference Board, 1973). SOCAP/TARP (1988) found that most organisations provided their personnel with formal training. This concerned such matters as company policies $(91 \%)$, telephone techniques $(88 \%)$, product information $(83 \%)$ and 
dealing with angry customers (81\%). As far as motivation is concerned, incentive systems for complaint management personnel consist of both economic and non-economic incentives (TARP, 1986). Important non-economic incentives are top management support, formal merit citations and the permission to perform an analysis of the data.

Managing resources refers to the means that are used to support complaint management activities. Recent developments in communication and information technology enable organisations to manage customer complaints in an efficient manner (Riemer, 1986; Shostak, 1989). The state-of-the art complaint management unit uses technologies such as telephone data collection systems and computer-based data analysis systems (Goodman and Malech, 1985; Riemer, 1986; TARP, 1986; SOCAP/TARP, 1988; SOCAP, 1990). The management of these resources concerns such matters as design, implementation and maintenance.

Controlling is the function of complaint management concerned with comparing actual performance with predetermined objectives and undertaking any necessary corrective action. Two measures of performance can be distinguished: efficiency and effectiveness (Schaefer, 1988). Efficiency is a measure that compares input and output in terms of (1) time standards (e.g., the time it takes to respond to a particular complaint), (2) cost standards (e.g., the average cost of handling a complaint), (3) quality standards (e.g., the accuracy of the data collection methods used), (4) productivity standards (e.g., the number of complaints dealt with in a set time period) and (5) behavioral standards (e.g., courteousness of complaint management personnel). Objectives of complaint management are defined in terms of restoration of complainant satisfaction and generation of preventive and corrective feedback for management. The control measure of effectiveness, therefore, looks at how information generated by complaint management meets these objectives. With regard to external customers, this means measuring the number of satisfactorily resolved complaints, the impact of complaint management in terms of customer loyalty and corporate image. With regard to internal customers, effectiveness can be measured in terms of real and perceived value for management decision-making. Real value refers to the extent to which information on the basis of complaints has been actually used for decision-making, while perceived value refers to management's satisfaction with the information.

This concludes our discussion of the constituent functions of a complaint management system. We will now attempt to show why and how the use of such systems has become particularly important for organisations due to recent European legal developments in the field of product safety and liability.

\section{European legal developments on product liability and product safety}

The legal climate in the European Community on product liability/product safety in the 1990s will be dominated by two regulations: the directive concerning liability for defective products (product liability) and the directive concerning general product safety published in Brussels, August 1992. In the context of European law a "directive" is an instruction to the member states to incorporate a set of rules into their own national bodies of law within a certain period of time. Aithough some countries are still in the process of incorporation, the directive on product liability had to be in force in the member states by July 1988. The directive on product safety has come into force in 1992 and it is to be expected that the member states will be allowed some time for national implementation. 
Although both directives are important in the context of progressively establishing the internal common market over a period expiring on December 31, 1992, we will not go into the legal structure of supranational European law, nor will we discuss legal details that numerous authors have put forward on these regulations. Coe (1987) compares the European Community with the United States, provides the text of the directive on product liability and gives information on the European legal system. Reich (1986) discusses this directive in more depth, but his article may not be fully accessible to readers without legal expertise. Mann and Rodrigues (1988) deal especially with product liability in the Netherlands and with the transformation of this directive into Dutch law. Hondius (1989) researched the impact of the product liability directive on legal developments and consumer protection in Western Europe and its relevance to Australia (1990). How product liability rules in particular affect weak consumers has been studied by Cavanillas Múgica (1950).

Obviously, there is yet little literature on the directive on product safety. Falke (1989) gives some highlights. Weatherill (1990) studied the directive irom a British point of view. The most comprehensive study of European product safety law, until now, is by Joerges (1990). The above mentioned authors give useful information and present many references for further insights.

\subsection{Main items of the directive on product liability}

The central rule of Directive 85/374/CEE reads: "The producer shall be liable for damage caused by a defect in his product."

"Product" means almost all movable goods, even though incorporated into another movable or into an immovab Electricity is included.

"Producer" is almost everyone: manufac- turer of a finished product or of a component part, producer of any raw material and furthermore anyone who presents himself as a producer by putting his name, trademark or other distinguishing feature on the product. Anyone who imports a product into the European community is also treated as "producer".

A product is defective when it does not provide the safety which a person is entitled to expect. All circumstances must be taken into account, including the presentation of the product, the reasonably expected use and the time when put into circulation.

"Damage" is limited to damage caused by death or personal injury and, furthermore, damage to or destruction of any item of property other than the defective product itself, provided that this item is of a type ordinarily intended and used mainly for private use or consumption. An attentive reader may conclude correctly that the directive covers all personal injuries but keeps relevant damage to material goods within the sphere of the ultimate consumer or user. In the case of personal injuries the directive goes beyond consumer protection.

Although better consumer protection is an important goal of this new regulation, a substantial burden of proof still lies with the person who suffers: he or she is required to prove the damage, the defect and the causal relationship between defect and damage.

The core of the directive is the limitation of accepted means of defense. This limitation results in improved consumer protection because if a producer does not succeed in using these means of defense convincingly, he will be held liable. Some legal details of the directive may show implicit possibilities to escape liability; nevertheless we focus on the means of defense the directive explicitly allows the producer to use.

The producer shall not be liable if he proves (occasionally we shorten parts of the official text): 
(a) that he did not put the product into circulation; or

(b) that it is probable that the defect which caused the damage did not exist at the time when the product was put into circulation by him or that this defect came into being afterwards; or

(c) that the product was neither manufactured nor distributed by him in the course of his business; or

(d) that the defect is due to compliance of the product with mandatory public regulations; or

(e) that the state of scientific and technical knowledge at the time when the product was put into circulation was not such as to enable the existence of the defect to be discovered; or

(f) in the case of a component manufacturer, that the defect is attributable to the design of the product in which the component has be fitted or to the instructions given by the manufacturer of the product.

Even when all member states will have incorporated this directive in their legislation, the regulation of product liability in the European Community will be only partly unified, for several reasons. One of these is that the directive contains three options (in fact the price that had to be paid in order to achieve consensus between member states): (1) primary agricultural products can be inor excluded, (2) any member state can decide to exclude the "state of the art" defense (see (e) above), (3) any member state can decide that a producer's total liability for damage resulting from death or personal injury and caused by identical products with the same defect shall be limited to an amount of 70 million ECU.

A further harmonisation of the product liability laws of the member states is possible because every five years the situation will be examined by the European Commission. New proposals might well be the outcome of these evaluations.

\subsection{Main items of the directive on product safety}

The core of Directive $92 / 228 / \mathrm{CEE}$ is a general safety rule directed at the member states; these have to take all the necessary measures in order to ensure that only safe products are marketed. In contrast to the directive on product liability (3.1 above) "product" is defined in the broadest possible sense. Its scope is explicitly not limited to consumer products, it covers the whole foreseeable product lifetime when used for its intended purpose, or in a manner which may reasonably be foreseen and with regard, in particular, to the normal behaviour of children. "Product" includes any part of it, like raw materials, substances or components. Even semi-finished and second-hand commodities are "products" in the scope of this directive.

A product is "safe" if it does not present an unacceptable risk for the safety and health of persons. All characteristics of the product are relevant in this respect: design, composition, execution, functioning, wrapping, conditions of assembly, maintenance or disposal and instructions for handling and use.

The general safety rule mentioned above moreover includes that if a product-because of its nature or for technical or economic reasons-presents a significant risk which is acceptable as such, this risk has to be appropriately indicated. This warning shall enable any intended or potential user of the product to make his own assessment of the risk before he acquires or uses the product.

Member states are required to place suppliers under the obligation to market only safe products. "Supplier" means the manufacturer and any person presenting himself as such (e.g., by using his own trademark), the manufacturer's authorized agent in the 
European Community or the EC importer of the product, and even other distributors in the supply chain if their activities may affect the safety of a marketed product (e.g. storage).

In order to assess the conformity of a product with the general safety rule, the directive provides a multi-criteria approach:

(1) the product must conform with specific European Community rules concerning health and safety requirements;

(2) in the case of absence of Community rules, the product must conform with specific rules on health and safety requirements of the national law of the member state where it is put on the market (provided that these national rules do not interfere with the section in the EC Treaty on the free movement of goods);

(3) while applying specific Community rules (1, above) or national rules (2, above) one must also take into account European and national standards or technical specifications for the product concerned, if any;

(4) in the absence of specific rules $(1,2$, above) or standards (3, above) the assessment of conformity with the general safety rule shall be made with reference to more general criteria like the state of the art of scientific and technical knowledge, codes of good practice, etc.;

(5) despite conformity with rules, standards and codes (1-4, above), authorities of member states are in any case entitled to put restrictions on the marketing of products or require withdrawals from the market and recalls from the users in case of evidence that a product is threatening the health and safety of persons.

Besides the duty of suppliers to provide buyers and users with information relevant to the assessment of safety risks of the product concerned, suppliers are also forced to monitor the safety of marketed products in order to be able to take action if unacceptable risks do occur. According to the directive this monitoring duty includes: identifying product lots by marking, sample testing of (already) marketed products and the institution of systematic procedures for assessing and investigating complaints made by users.

The directive obliges member states to establish national authorities to see that suppliers act in compliance with the safety, warning and monitoring rules. These authorities can be given, among others, the following powers: requesting all relevant information and samples of a product from suppliers, issuing public warnings, the restriction of distribution and marketing, requesting appropriate changes in a product or prohibiting its further manufacture, inviting voluntary recall or ordering a manufacturer to recall the product. These authorities have to collect and analyze information on health and safety risks and give due consideration to complaints by the public about safety properties of marketed products.

Finally, the directive provides for a system of fast exchange of information between member states in cases of unacceptable product risks. An authority of a member state is obliged to notify the European Commission of all measures issued to prevent a health risk within a short period. The Commission can urge authorities of other member states to take appropriate measures immediately to protect their citizens against that hazard.

\subsection{Regulation of product liability and product safety: two sides of a coin}

From a strict legal point of view, product liability and product safety regulations are separate systems of rules and differ in nature. Regulation of product safety is part of the body of public law in which governments have the power to impose obligations on 
suppliers. Regulation of product liability belongs to the domain of private law (of contracts and tort) in which injured users of products can go to court and claim for compensation of damages. From a societal point of view, though, product liability and product safety regulations are complementary. With product safety the legislature strives for prevention of injuries. In the case of failure or absence of prevention, product liability is needed as a means and procedure of compensation for damage suffered.

It is becoming rather obvious that in modern societies it is not enough to have only product liability regulation. Christoffel (1989) argues that product liability lawsuits are flawed quality mechanisms. Earlier Bardach and Kagan (1982) concluded likewise. Court procedures are complicated, time consuming and costly, the parties involved are not equal, etc.; product liability regulation is a poor problem solution mechanism and cannot serve society adequately. According to Dardis (1988), Hjorth-Andersen (1987) and Joerges (1986) markets are imperfect because price is a bad indicator of product quality and therefore of product safety. A thought provoking overview of legal approaches to safety risks is offered by Asch (1988). Furthermore, in member states that allow the producer to use the "state of the art" option as a means of defense, it is the innocent injured person "who is obliged to bear his own loss", as Weatherill (1987) has put it.

Product safety comes first and it is the manufacturer who has to produce it. If the producer can or will not meet the demands of the public's right to safety, governments have to take over this responsibility by using measures like public warnings and compulsory withdrawals and recalls on behalf and at the cost of the producer. Product liability comes second and provides compensation for damage that occurs despite preventive policies. The better the product safety prevention system works, the less important product liability becomes. Product safety and product liability are two sides of a coin with the powers of government as a defender of consumer rights (and responsible for public health and safety) engraved on the edge.

\section{From awareness to diagnosis and remedy}

Brack and Gieskes (1990) demonstrate that product liability and product safety are phenomena with high relevance to Total Quality Management. This insight forms the key to a professional managerial approach of product liability and product safety issues. They advise the formation of an in-company multidisciplinary task force of experts to audit organizational processes and procedures in order to develop preventive policies. These authors present an example of a checklist which, if elaborated in practice, can be used to map the actual corporate state of affairs on product liability and product safety vulnerability.

In a defensive marketing strategy it is of great importance that complaining customers swiftly get a positive response in order to prevent them from switching brands, from negative word of mouth, from filing a claim, etc. Moreover, a professional performance of the corporate legal department in modern business requires an anticipating attitude to protect the company against costly claims for damage. In both perspectives customer complaint management could render the company an important service as the following examples drawn from empirical research (De Ruyter, 1993) and our management consulting activities show.

A large American car manufacturer uses a computer based system that produces legal reports periodically. The system is operated such that, for instance, a "breach of warranty report" is produced monthly. The current month's report is accessible on line and data is stored by region. Similar reports are pro- 
duced for small claims court cases and for product liability lawsuits. Even the data of closed cases is stored to be consulted afterwards, if necessary in view of similar current cases. Furthermore, a report is viewable on line of all indemnification requests, accepted or denied.

One of the company's major competitors, a large Japanese car manufacturer, is presently experimenting to take the state of the art in complaint management software one step further. One of the company's regional Customer Assistance Centers has added a new module to its information system that relates the costs in each legal claim to the cost of arbitration. As a legal claim goes through the various stages of arbitration, the spreadsheet-based module indicates at which point it will be most advantageous for the company to settle.

Recently a Dutch company was forced by a public health agency to issue a writter warning to the buyers of a so-called "easy-off slimming belt". The company knew that users of the product risked medical problems. Instead of conducting a profound investigation of these problems, the company tended to deny their existence and overlooked the legal consequences. In the meantime publicity was doing harm, customers were lost and potential users deterred. Instead of negotiating and preparing legal procedures in order to mitigate the text of the written warning this firm could better have cared for its present customers and built an early warning system, preferably complaint data-based. The company concerned was a mail-order firm, and certainly able to run the customer complaints software. It can be proven that the purchase of complaint management software is costeffective. A US health insurance company which recently bought a complaint manageinent software package has found that legal costs resulting from customer dissatisfaction dropped $30 \%$ in the first six months. Although it is always difficult to establish a direct causal relationship, the consumer affairs and legal departments managed to convince company management that the investment had been a good one.

A defensive marketing strategy performed by a customer complaints management unit in close cooperation with the corporate legal affairs department can cope with the fact that governmental agencies and prosecutors will be better equipped to defend the consumer's right to safety. The burden of proof will become heavier for manufacturers and suppliers if a publicly accessible product safety database reveals that a company's product is not in compliunce with standards and regulations and/or has caused accidents. In February 1991 the Dutch Consumer Safety Institute, a private organisation which works in close cooperation with and is subsidised by the Ministry of Public Health, presented a memorandum entitled "Towards a Dutch Product Safety Database" (ISBN 90-6788-108-2). For purposes of research, governmental po:icy planning and criminal investigation the memo proposes to build a network between existing databases. This network can make better use of (new) European statutory regulations and should be most helpful in the new situation of the single European market by linking it to the European Home and Leisure Accident Surveillance System (EHLASS), a database of cases of product users who had medical treatment because of product related unsafety. If this becomes reality there will soon be a public network of decentralised databases, interrelated on a European scale, with information on separate products derived from consumer complaints and criminal investigation reports and with information on standards and regulations in the field of product safety as well. This information can be compared with available statistical material on accidents which makes data on unsafe products in the market easily accessible and specific. 
The corporate legal affairs department, in close cooperation with customer complaint management, should be very interested in methods to anticipate these developments in order to practice prevention of safety risks and of liability claims. In the field of product liability and product safety that is exactly what defensive marketing and complaint management is about.

\section{Summary}

In this article we have attempted to show how the notion of defensive marketing can take on a whole new meaning in the light of recent European legal developments on product safety and product liability. An outline was developed of a system of complaint management that companies may use to prevent signals of customer dissatisfaction from escalating to the level of claims for compensation of damage or injury. Since customer complaint management has entered the information age we have also tried to demonstrate how automated systems may enable companies to manage customer dissatisfaction more efficiently and effectively. So, on the basis of a pull originating from developments in the legal field and an information technology push we predict that automation of the consumer affairs departments in general and their interface with the legal department in particular, will prove to be an important issue which European companies and non-European exporters into the European Community will have to face.

\section{References}

Anton, J. and J.C. de Ruyter, 1991. Van klachten naar managementinformatie. Harvard Holland Review (26), 27-32.

Asch, P., 1988. Consumer safety regulation-Putting a price on life and limb. New York, NY: Oxford University Press.

Bardach, E. and R.A. Kagan, 1982. Going by the book-The problem of regulatory unreasonableness, 272 and 280 . Philadelphia, PA: Temple University Press.

Bonoma, T.V., 1985. The marketing edge. New York, NY: MacMillan.

Brack, A. and J.F.B. Gieskes, 1990. European legal developments in product liability and product safety and the total quality management approach. International Journal of Materials and Product Technology 5 (4), 311-326.

Cavanillas Múgica, S., 1990. Protection of the weak consumer under product liability ruies. Journal of Consumer Policy 13 (3), 299-309.

Christoffel, T., 1989. The role of law in reducing injury. Law, Medicine and Health Care 17 (1) (Spring), 7-16.

Coe, J.J. Jr., 1987. Products liability in the European Community-An introduction to the 1985 Council Directive. Journal of Products Liability 10, 197-224.

Conference Board, 1973. The consumer affairs department: Organization and functions. New York, NY: The Conference Board.

Dardis, R., 1988. Risk regulation and consumer welfare. Journal of Consumer Affairs 22 (2) (Winter), 303-318.

Davis, G.B. and M.H. Olson, 1884. Management information systems. Conceptual foundations, structure and development. New York, NY: McGraw-Hill.

De Ruyter, J.C., 1990. Consumer dissatisfaction and complaining behaviour: A decision process approach. SWOKA Research Report No. 98, SWOKA, The Hague.

De Ruyter, J.C., 1993. Dissatisfaction management. A study into the use of consumer dissatisfaction as a source of management information by organizations. Dissertation, University of Twente, Enschede.

Falke, J., 1989. Elements of a horizontal product safety policy for the European Community. Journal of Consumer Policy 12, 207-228.

Fornell, C., 1976. Consumer input for marketing decisions: A study of corporate departments for consumer affairs. New York, NY: Praeger.

Fornell, C., 1988. Corporate consumer affairs departments: Retrospect and prospect. In: E. Scott Maynes and The ACCI Research Committee (eds.), The frontier of research in the consumer interest, 595-619. American Council on Consumer Interests.

Fornell, C. and B. Wernerfelt, 1987. Defensive marketing strategy by complaint management: A theoretical analysis. Journal of Marketing Research 24, 337-346.

Fornell, C. and B. Wernerfelt, 1988. A model for customer complaint management. Marketing Science 7, 287-298.

Fornell, C. and R.A. Westbrook, 1984. The vicious circlt of consumer complaints. Journal of Marketing 48, 68-78.

Gilly, M.C. and W.B. Stevenson, 1988. Complaint managcment in the health care organisation. Journal of Consumer Satisfaction, Dissatisfaction and Complaining Behavior 1, 93-98

Goodman, J.A. and A.R. Malech, 1985. Using complaints for quality assurance decisions. Working Paper, TARP, Washington, DC.

Goodman, J.A., A.R. Malech and C. Adamson, 1988. A strategy for integrating service and quality data in a manner which reduces quality expenditures and allows compa- 
nies to estimate the payback from service improvements. Working Paper, TARP, Washington, DC.

Hansen, U., 1986. Dialogue between business and consumers in the process of product development. Paper presented at the Symposium on New Challenges for European Consumer Policy.

Hauser, J.R., 1984. Theory and application of defensive strategy. The Dean Symposium in Applied Economics, Columbia University.

Hauser, J.R. and S.P. Gaskin, 1984. Application of the defender consumer model. Marketing Science 3 (4), 327-351.

Hauser, J.R. and S.M. Shugan, 1983. Defensive marketing strategies. Marketing Science 2, 319-360.

Hirschman, A.O., 1970. Exit, voice and loyalty. Cambridge, MA: Harvard University Press.

Hjorth-Andersen, Chr., 1987. Price as a risk indicator. Journal of Consumer Policy 10, 267-281.

Hondius, E.H., 1989. The impact of the products liability directive on legal developments and consumer protection in Western Europe. Canterbury Law Review 4, 35-51.

Hondius, E.H., 1990. Products liability law in the EEC and its relevance to Australia. Australian Product Liability Reporter $1(5), 61-64,72$.

Joerges, Chr., 1986. Quality regulation in consumer goods markets. In: T. Daintith and G. Teubner (eds.), Contract and Organization. Berlin/New York: De Gruyter.

Joerges, Chr., 1990. Product safety law, internal market policy and the proposal for a directive on general product safety. Working Paper No. 90/3, European Policy Unit, European University Institute, Florence.

Kasper, J.D.P., 1982. Marketing en consumentensoevereiniteit. Amsterdam: VU Boekhandel/Uitgeverij.

Mann, L. and P.R. Rodrigues, 1988. The European directive on products liability: The promise of progress? The Georgia Journal of International and Comparative Law 18, $391-426$.
Mintzberg, H., 1979. The structuring of organizations. Englewood Cliffs, NJ: Prentice Hall.

Plymire, J., 1991. Complaints as opportunities. Business Horizons (Mar.-Apr.), 79-81.

Reich, N., 1986. Product safety and product liability-An analysis of the EEC Council Directive of 25 July 1985 on the approximation of the laws, regulations, and administrative provisions of the $m$ :mber states concerning liability for defective products. Journal of Consumer Policy 9, 133-154.

Riemer, M., 1986. Beschwerdemanagement. Frankfurt/New York: Campus Verlag.

Schaefer, G., 1988. Functional analysis of office requirements. A multiperspective approach. Chichester: John Wiley and Sons.

Shostak, A., 1989. Technological forecasts and the changing consumer. Mobius, 11-13. Alexandria: SOCAP.

SOCAP, 1990. Computer technology in consumer affairs. Alexandria: SOCAP.

SOCAP/TARP, 1988. 800 numbers for customer service: A 1988 profile. Alexandria: SOCAP.

TARP, 1986. Consumer complaint handling in America: An update study. Washington, DC: United States Office of Consumer Affairs.

Ulincy, M.F., 1989. Product liability: The role of consumer affairs. Mobius, 23-26. Alexandria: SOCAP.

Weatherill, S., 1987. Consumer safety legislation in the United Kingdom. European Consumer Law Journal (2), 81-96.

Weatherill, S., 1990. A general duty to supply only safe goods in the community: Some remorks from a British perspective. Journal of Consumer Policy 13 (1), 79-89.

Wimmer, F., 1985. Beschwerdenpolitik als zentrales Tatigheitsfeld von Verbracherabteilungen. In: U. Hansen and I. Schoenheit, Verbraucherabteilungen in privaten und öffentlichen Unternehmen, 225-254. Frankfurt/New York: Campus Verlag. 